
3 Research Square
Preprints are preliminary reports that have not undergone peer review.
They should not be considered conclusive, used to inform clinical practice, or referenced by the media as validated information.

\title{
Unhealthy Behaviors and Metabolic Indices of Chronic Kidney Disease in a HCV Hyperendemic Area: A Community-Based Study
}

Mei-Yen Chen

Chang Gung University of Science and Technology College of Nursing

Po-Chang Wang

Chang Gung Memorial Hospital Chiayi Branch: Chiayi Chang Gung Memorial Hospital

Ming-Shyan Lin

Chang Gung Memorial Hospital Chiayi Branch: Chiayi Chang Gung Memorial Hospital

Chun-Liang Lin

Chang Gung Memorial Hospital Chiayi Branch: Chiayi Chang Gung Memorial Hospital

\section{Chang-Min Chung}

Chang Gung Memorial Hospital Chiayi Branch: Chiayi Chang Gung Memorial Hospital

Yu-Sheng Lin

Chang Gung Memorial Hospital Chiayi Branch: Chiayi Chang Gung Memorial Hospital

Yi Fang Wu ( $\nabla$ yvonnearea@gmail.com )

Chang Gung Memorial Hospital Chiayi Branch: Chiayi Chang Gung Memorial Hospital https://orcid.org/0000-0003-4287-8850

\section{Research}

Keywords: chronic kidney disease, hepatitis C virus, metabolic syndrome, exercise, dietary behavior

Posted Date: July 8th, 2021

DOI: https://doi.org/10.21203/rs.3.rs-684455/v1

License: (a) (1) This work is licensed under a Creative Commons Attribution 4.0 International License. Read Full License 


\section{Abstract}

Background: Hepatitis C virus (HCV) infection is related to a higher risk of chronic kidney disease (CKD). This study aimed to investigate the relationships between unhealthy behaviors, metabolic indices, and HCV with CKD.

Methods: This cross-sectional study was conducted as part of a community health promotion program in the HCV hyperendemic area of Taiwan between March and December 2019. Multivariable logistic regression analyses adjusted for demographic and clinical characteristics were performed to investigate the association between CKD and HCV seropositivity.

Results: A total of 2,387 patients completed the examination. HCV was related to a lower estimated glomerular filtration rate (eGFR), unhealthy dietary behaviors, and multiple metabolic indices including higher systolic blood pressure (SBP), glycosylated hemoglobin ( $\mathrm{HbA1c}$ ), and triglycerides (TG), and lower high-density lipoprotein (HDL). HCV was associated with a 44\% higher risk of CKD compared to non-HCV (OR 1.44, 95\% confidence interval [Cl] 1.05-1.98). Irregular exercise, waist circumference (WC), and higher $\mathrm{HbA1c}$ were significantly associated with a higher risk of CKD after multivariable analysis. A low eGFR was significantly associated with the severity of metabolic syndrome (MetS) in the HCV group (median eGFR of $86.4,77.1$, and $64.5 \mathrm{~mL} / \mathrm{min} / 1.73 \mathrm{~m}^{2}$ for individuals with one, three, and five MetS components, respectively).

Conclusions: HCV seropositivity, metabolic distortion, and irregular exercise are significantly associated with CKD. Effective treatment of HCV and aggressive health promotion of physical activity may prevent the occurrence of CKD.

\section{Background}

Hepatitis $\mathrm{C}$ virus (HCV) infection is a global health issue that affects approximately 71.1 million people worldwide (1). HCV infection is a significant cause of liver cirrhosis, hepatocellular carcinoma, and increases the risk of chronic kidney disease (CKD). In Taiwan, CKD has been identified as a poor prognostic factor and confers a large health insurance premium burden.

Early studies reported conflicting relationships between $\operatorname{HCV}$ and $\operatorname{CKD}(2,3)$; however, recent research has more consistently indicated that patients with HCV have a higher risk of CKD than individuals without HCV (4-6). Several measures to reduce the rate of deterioration in renal function are under investigation in patients with CKD, including increased physical activity, dietary intervention, and management of metabolic syndrome (MetS) (7-9). However, few studies have focused on the features of patients with $\mathrm{CKD}$ and HCV. Therefore, the relationships between unhealthy behaviors, metabolic indices, and renal dysfunction in HCV remain unclear.

Thus, we conducted a community-based investigation in a hyper-endemic area of HCV infection in Taiwan, where the estimated seroprevalence is $4.4 \%(10)$. This study aimed to explore the relationships 
between unhealthy behaviors, metabolic disturbances, and HCV with CKD.

\section{Methods}

This community-based study was conducted in rural areas on the western coast of Taiwan, in Yunlin County. The cross-sectional data were drawn from annual health check-ups during a nurse-led community health promotion program conducted between March and December 2019. The inclusion criteria were patients aged 18 to 80 -years-old who agreed to sign the informed consent form. Participants without complete laboratory data and informed consent forms were excluded.

This study was approved by the Institutional Review Board (IRB NO: 201900222A3). The research assistants obtained informed consent from all participants. All research assistants had received two hours of questionnaire interview training by an investigator. Interviews with pilot participants confirmed a $90 \%$ rate of inter-rater reliability. All study participants completed a 10-minute interview using a structured questionnaire and donated a blood sample after fasting overnight for 8 hours. Data on the demographic and clinical characteristics of the study participants were collected, including gender, age, education level, dietary behaviors, irregular exercise, and substance use. Healthy dietary behaviors were defined by a vegetable intake $\geq$ three portions per day (one portion is equivalent to $100 \mathrm{~g}$ edible vegetables), fruit intake $\geq$ two portions per day (one portion is equivalent to $100 \mathrm{~g}$ edible fruits), and water intake $\geq 1500 \mathrm{cc}$ per day according to the daily dietary guidelines suggested by the Health Promotion Administration of Taiwan Ministry of Health and Welfare (11).

Clinical examination data related to metabolic syndrome and chronic hepatitis were also obtained, including waist circumference (WC), systolic blood pressure (SBP), diastolic blood pressure (DBP), highdensity lipoprotein (HDL), glycosylated hemoglobin ( $\mathrm{HbA1c}$ ), triglycerides $(\mathrm{TG})$, aspartate aminotransferase (AST), alanine aminotransferase (ALT), and estimated glomerular filtration rate (eGFR). A patient was determined to be infected with HCV if the anti-HCV antibody test was positive, infected with hepatitis B virus (HBV) if the HBV surface antigen test was positive, or classified into the non-hepatitis group if both enzyme-linked immunosorbent assay tests were negative. In addition, subjects with HBV and HCV co-infection were excluded from the analysis.

Components related to metabolic syndrome included a $W C \geq 90 \mathrm{~cm}$ for males or $\geq 80 \mathrm{~cm}$ for females, $\mathrm{SBP}>130 \mathrm{mmHg}$ or DBP $>85 \mathrm{mmHg}, \mathrm{HDL}<40 \mathrm{mg} / \mathrm{dL}$ for males or $<50 \mathrm{mg} / \mathrm{dL}$ for females, $\mathrm{TG} \geq 150$ $\mathrm{mg} / \mathrm{dL}$, and $\mathrm{HbA} 1 \mathrm{c} \geq 5.7 \%$. Metabolic syndrome was diagnosed if three or more of the five components were present (12-16).

\section{Statistical analysis}

The demographic, dietary and clinical characteristics of the study subjects in the hepatitis status groups (non-hepatitis vs. HBV vs. HCV) were compared using one-way analysis of variance for continuous variables or the Chi-square test for categorical variables. Pairwise comparisons were performed using Bonferroni adjustment if the overall difference was significant. The demographic, dietary and clinical 
characteristics of the study subjects with and without CKD were compared using the independent sample $t$ t-test for continuous variables or Chi-square test for categorical variables. A series of univariate logistic regression analyses were conducted to screen for factors potentially associated with CKD (defined as eGFR $<60 \mathrm{~mL} / \mathrm{min} / 1.73 \mathrm{~m}^{2}$ ). Variables with a significance level less than 0.15 were further incorporated into a multivariable logistic regression model with a backward elimination (17). All tests were two-tailed and $P<0.05$ was considered statistically significant. Data analyses were conducted using IBM SPSS Statistics for Windows, version 25 (IBM Corp., Armonk, NY, USA).

\section{Results}

A total of 2,387 subjects with complete examination data were analyzed in this study, of whom 213 (8.9\%) and 306 (12.8\%) subjects were seropositive for HBV and HCV, respectively (Table 1). The mean participant age was 64.1 years old $(\mathrm{y} / \mathrm{o})$; females accounted for $63.2 \%$ of all participants. The individuals in the HCV group were older (70.8 y/o), had a lower education level, were less likely to have healthy dietary behaviors, and were more likely to chew or consume betel compared to the HBV and non-hepatitis groups. In addition, the HCV group had higher SBP, HbA1c, and TG, and lower HDL, and were more likely to have metabolic syndrome. Higher AST and ALT, and lower eGFR were also noted in the HCV group. There were no differences in gender, WC, irregular exercise, smoking, and consumption of alcohol among the three groups (Table 1). 
Table 1

Demographics and characteristics of the study subjects according to the HBV and HCV status $(N=2,387)$

\begin{tabular}{|c|c|c|c|c|c|}
\hline Variable & Total & $\begin{array}{l}\text { Non- } \\
\text { hepatitis }\end{array}$ & HBV & HCV & $P$ \\
\hline Number of subjects & 2,387 & 1,868 & 213 & 306 & \\
\hline Female & $\begin{array}{l}1,508 \\
(63.2)\end{array}$ & $\begin{array}{l}1,160 \\
(62.1)\end{array}$ & $138(64.8)$ & 210 (68.6) & 0.079 \\
\hline Age, years & $\begin{array}{l}64.1 \pm \\
14.9\end{array}$ & $63.3 \pm 15.6$ & $61.1 \pm 12.3$ & $\begin{array}{l}70.8 \pm \\
10.0^{\mathrm{a}, \mathrm{b}}\end{array}$ & $<.001$ \\
\hline Age group & & & & & $<.001$ \\
\hline$<40$ years & $213(8.9)$ & $199(10.7)$ & $14(6.6)$ & $0(0.0)^{a, b}$ & \\
\hline $40-64$ years & $838(35.1)$ & $653(35.0)$ & $104(48.8)^{a}$ & $81(26.5)^{a, b}$ & \\
\hline$\geq 65$ years & $\begin{array}{l}1,336 \\
(56.0)\end{array}$ & $\begin{array}{l}1,016 \\
(54.4)\end{array}$ & $95(44.6)^{\mathrm{a}}$ & $\begin{array}{l}225 \\
(73.5)^{a, b}\end{array}$ & \\
\hline Education level, years & $6.6 \pm 5.4$ & $6.9 \pm 5.5$ & $7.7 \pm 5.0$ & $3.9 \pm 4.2^{a, b}$ & $<.001$ \\
\hline \multicolumn{6}{|l|}{ Dietary behaviour } \\
\hline $\begin{array}{l}\text { Intake vegetable } \geq 3 \text { portions per } \\
\text { day }\end{array}$ & $\begin{array}{l}1,592 \\
(66.7)\end{array}$ & $\begin{array}{l}1,279 \\
(68.5)\end{array}$ & $140(65.7)$ & $173(56.5)^{\mathrm{a}}$ & $<.001$ \\
\hline Intake fruit $\geq 2$ portions per day & $\begin{array}{l}1,337 \\
(56.0)\end{array}$ & $\begin{array}{l}1,079 \\
(57.8)\end{array}$ & $118(55.4)$ & $140(45.8)^{\mathrm{a}}$ & $<.001$ \\
\hline Intake of water $\geq 1500 \mathrm{cc}$ per day & $\begin{array}{l}1,402 \\
(58.7)\end{array}$ & $\begin{array}{l}1,139 \\
(61.0)\end{array}$ & $118(55.4)$ & $145(47.4)^{\mathrm{a}}$ & $<.001$ \\
\hline Irregular exercise & $\begin{array}{l}1,660 \\
(69.5)\end{array}$ & $\begin{array}{l}1,295 \\
(69.3)\end{array}$ & $145(68.1)$ & 220 (71.9) & 0.589 \\
\hline \multicolumn{6}{|l|}{ Substance use } \\
\hline Smoking & 427 (17.9) & $332(17.8)$ & $37(17.4)$ & $58(19.0)$ & 0.864 \\
\hline Betel & $221(9.3)$ & $164(8.8)$ & $14(6.6)$ & $43(14.1)^{a, b}$ & 0.005 \\
\hline Alcoholic drinking & $241(10.1)$ & $183(9.8)$ & $29(13.6)$ & $29(9.5)$ & 0.200 \\
\hline
\end{tabular}

HBV, hepatitis B virus; $H C V$, hepatitis C virus; ALT, alanine aminotransferase; AST, aspartate aminotransferase; eGFR, estimated Glomerular filtration rate;

"a" and "b" indicate significant difference versus the "Non-HBV \& Non-HCV" and "HBV only" groups in the Bonferroni multiple comparison, respectively;

Data were presented as mean \pm standard deviation or frequency and percentage. 


\begin{tabular}{|c|c|c|c|c|c|}
\hline Variable & Total & $\begin{array}{l}\text { Non- } \\
\text { hepatitis }\end{array}$ & HBV & HCV & $P$ \\
\hline \multicolumn{6}{|l|}{$\begin{array}{l}\text { Data of metabolic syndrome } \\
\text { (MetS) }\end{array}$} \\
\hline Waist circumference (WC), cm & $\begin{array}{l}84.8 \pm \\
10.8\end{array}$ & $84.8 \pm 10.9$ & $84.3 \pm 10.7$ & $85.2 \pm 10.0$ & 0.611 \\
\hline Systolic blood pressure, $\mathrm{mmHg}$ & $\begin{array}{l}134.7 \pm \\
20.4\end{array}$ & $\begin{array}{l}134.7 \pm \\
20.1\end{array}$ & $\begin{array}{l}131.6 \pm \\
21.0\end{array}$ & $\begin{array}{l}137.0 \pm \\
21.2^{\mathrm{b}}\end{array}$ & 0.013 \\
\hline Diastolic blood pressure, $\mathrm{mmHg}$ & $\begin{array}{l}81.7 \pm \\
12.4\end{array}$ & $81.8 \pm 12.2$ & $82.3 \pm 13.1$ & $80.4 \pm 12.6$ & 0.141 \\
\hline High-density lipoprotein, mg/dL & $\begin{array}{l}51.0 \pm \\
13.2\end{array}$ & $51.2 \pm 13.0$ & $52.9 \pm 13.5$ & $\begin{array}{l}49.1 \pm \\
13.9^{\mathrm{a}, \mathrm{b}}\end{array}$ & 0.004 \\
\hline $\begin{array}{l}\text { Glycosylated hemoglobin, } \\
\text { mg/dL }\end{array}$ & $6.1 \pm 1.1$ & $6.1 \pm 1.0$ & $6.0 \pm 1.0$ & $6.3 \pm 1.3^{\mathrm{a}, \mathrm{b}}$ & 0.011 \\
\hline Triglyceride, mg/dL & $\begin{array}{l}137.8 \pm \\
96.1\end{array}$ & $\begin{array}{l}140.1 \pm \\
98.7\end{array}$ & $\begin{array}{l}117.8 \pm \\
82.1^{\mathrm{a}}\end{array}$ & $\begin{array}{l}137.4 \pm \\
87.5\end{array}$ & 0.006 \\
\hline MetS & $\begin{array}{l}1,242 \\
(52.0)\end{array}$ & $973(52.1)$ & $89(41.8)^{a}$ & $180(58.8)^{b}$ & 0.001 \\
\hline \multicolumn{6}{|l|}{ Liver and renal function } \\
\hline ALT, U/L & $\begin{array}{l}25.6 \pm \\
13.3\end{array}$ & $24.8 \pm 11.6$ & $26.9 \pm 11.2$ & $\begin{array}{l}29.8 \pm \\
21.3^{a, b}\end{array}$ & $\begin{array}{l}<.001 \\
0.001\end{array}$ \\
\hline AST, U/L & $\begin{array}{l}24.0 \pm \\
18.9\end{array}$ & $23.4 \pm 18.6$ & $25.9 \pm 17.7$ & $26.1 \pm 21.2$ & 0.020 \\
\hline eGFR, $\mathrm{ml} / \mathrm{min} / 1.73 \mathrm{~m}^{2}$ & $\begin{array}{l}84.6 \pm \\
24.4\end{array}$ & $85.4 \pm 24.5$ & $87.8 \pm 21.7$ & $\begin{array}{l}77.2 \pm \\
23.7^{a, b}\end{array}$ & $<.001$ \\
\hline $\mathrm{eGFR}<60 \mathrm{ml} / \mathrm{min} / 1.73 \mathrm{~m}^{2}$ & $342(14.3)$ & $250(13.4)$ & $19(8.9)$ & $73(23.9)^{a, b}$ & $\begin{array}{l}<.001 \\
0.001\end{array}$ \\
\hline \multicolumn{6}{|c|}{$\begin{array}{l}\text { HBV, hepatitis B virus; HCV, hepatitis C virus; ALT, alanine aminotransferase; AST, aspartate } \\
\text { aminotransferase; eGFR, estimated Glomerular filtration rate; }\end{array}$} \\
\hline \multicolumn{6}{|c|}{$\begin{array}{l}\text { "a" and "b" indicate significant difference versus the "Non-HBV \& Non-HCV" and "HBV only" groups in } \\
\text { the Bonferroni multiple comparison, respectively; }\end{array}$} \\
\hline
\end{tabular}

We further compared the characteristics of the subjects with and without CKD (Table 2). The individuals with CKD were older, less likely to be female, had a lower education level, had poorer dietary behaviors, and were less likely to exercise regularly. Subjects with CKD also had a higher frequency of components of metabolic syndrome, including higher WC, SBP, HbA1c, and TG, lower DBP, and lower HDL. The prevalence of metabolic syndrome was higher in the CKD group than the non-CKD group. There were no 
differences in substance use among the two subgroups. Moreover, the CKD group had poorer liver function (ALT) and a higher prevalence of HCV (21.3\% vs. 11.4\%; Table 2). 
Table 2

Demographics and characteristics of the study subjects according to the renal function status $(N=2,387)$

\begin{tabular}{|c|c|c|c|}
\hline Variable & $\begin{array}{l}\text { eGFR }<60 \\
\mathrm{ml} / \mathrm{min} / 1.73 \mathrm{~m}^{2}\end{array}$ & $\begin{array}{l}\text { eGFR } \geq 60 \\
\mathrm{ml} / \mathrm{min} / 1.73 \mathrm{~m}^{2}\end{array}$ & $P$ \\
\hline Number of subjects & 342 & 2,045 & \\
\hline Female & $194(56.7)$ & $1,314(64.3)$ & 0.008 \\
\hline Age, years & $74.8 \pm 9.1$ & $62.3 \pm 15.0$ & $\dot{0.001}$ \\
\hline Age group & & & $\dot{0.001}$ \\
\hline$<40$ years & $0(0.0)$ & $213(10.4)$ & \\
\hline $40-64$ years & $38(11.1)$ & $800(39.1)$ & \\
\hline$\geq 65$ years & $304(88.9)$ & $1,032(50.5)$ & \\
\hline Education level, years & $3.7 \pm 4.3$ & $7.1 \pm 5.5$ & $\begin{array}{l}< \\
0.001\end{array}$ \\
\hline \multicolumn{4}{|l|}{ Dietary behaviour } \\
\hline $\begin{array}{l}\text { Intake vegetable } \geq 3 \text { portions per } \\
\text { day }\end{array}$ & $196(57.3)$ & $1,396(68.3)$ & $<.001$ \\
\hline Intake fruit $\geq 2$ portions per day & $149(43.6)$ & $1,188(58.1)$ & $\begin{array}{l}< \\
0.001\end{array}$ \\
\hline Intake of water $\geq 1500 \mathrm{cc}$ per day & $172(50.3)$ & $1,230(60.1)$ & 0.001 \\
\hline Irregular exercise & $257(75.1)$ & $1,403(68.6)$ & 0.015 \\
\hline \multicolumn{4}{|l|}{ Substance use } \\
\hline Smoking & $71(20.8)$ & $356(17.4)$ & 0.134 \\
\hline Betel & $41(12.0)$ & $180(8.8)$ & 0.060 \\
\hline Alcoholic drinking & $38(11.1)$ & $203(9.9)$ & 0.501 \\
\hline \multicolumn{4}{|l|}{$\begin{array}{l}\text { Data of metabolic syndrome } \\
\text { (MetS) }\end{array}$} \\
\hline Waist circumference (WC), $\mathrm{cm}$ & $88.3 \pm 10.1$ & $84.2 \pm 10.8$ & $\dot{0.001}$ \\
\hline Systolic blood pressure, $\mathrm{mmHg}$ & $137.5 \pm 21.7$ & $134.2 \pm 20.1$ & 0.006 \\
\hline
\end{tabular}

eGFR, estimated Glomerular filtration rate; ALT, alanine aminotransferase; AST, aspartate aminotransferase; HBV, hepatitis B virus; $\mathrm{HCV}$, hepatitis $\mathrm{C}$ virus;

Data were presented as mean \pm standard deviation or frequency and percentage; 


\begin{tabular}{|c|c|c|c|}
\hline Variable & $\begin{array}{l}\text { eGFR }<60 \\
\mathrm{ml} / \mathrm{min} / 1.73 \mathrm{~m}^{2}\end{array}$ & $\begin{array}{l}\text { eGFR } \geq 60 \\
\mathrm{ml} / \mathrm{min} / 1.73 \mathrm{~m}^{2}\end{array}$ & $P$ \\
\hline Diastolic blood pressure, $\mathrm{mmHg}$ & $79.2 \pm 13.4$ & $82.1 \pm 12.1$ & $\begin{array}{l}< \\
0.001\end{array}$ \\
\hline High-density lipoprotein, mg/dL & $45.2 \pm 12.7$ & $52.0 \pm 13.0$ & $<.001$ \\
\hline Glycosylated hemoglobin, mg/dL & $6.4 \pm 1.2$ & $6.0 \pm 1.0$ & $<.001$ \\
\hline Triglyceride, mg/dL & $159.2 \pm 91.7$ & $134.2 \pm 96.4$ & $\begin{array}{l}<.001 \\
0.00\end{array}$ \\
\hline MetS & $233(68.1)$ & $1,009(49.3)$ & $<.001$ \\
\hline \multicolumn{4}{|l|}{ Liver and renal function } \\
\hline $\mathrm{ALT}, \mathrm{U} / \mathrm{L}$ & $27.0 \pm 12.4$ & $25.4 \pm 13.4$ & 0.045 \\
\hline AST, U/L & $22.6 \pm 16.5$ & $24.2 \pm 19.2$ & 0.145 \\
\hline eGFR, $\mathrm{ml} / \mathrm{min} / 1.73 \mathrm{~m}^{2}$ & $46.9 \pm 11.5$ & $90.9 \pm 19.8$ & $<.001$ \\
\hline HBV and HCV status & & & $<.001$ \\
\hline Non-hepatitis & $250(73.1)$ & $1,618(79.1)$ & \\
\hline HBV & $19(5.6)$ & $194(9.5)$ & \\
\hline $\mathrm{HCV}$ & $73(21.3)$ & $233(11.4)$ & \\
\hline \multicolumn{4}{|c|}{$\begin{array}{l}\text { eGFR, estimated Glomerular filtration rate; ALT, alanine aminotransferase; AST, aspartate } \\
\text { aminotransferase; HBV, hepatitis B virus; HCV, hepatitis C virus; }\end{array}$} \\
\hline
\end{tabular}

All variables were included in a series of univariate logistic regression analyses to investigate the factors potentially associated with CKD (Table 3 ). Older age (odds ratio [OR] 1.08, 95\% confidence interval [Cl] 1.07-1.10), irregular exercise (OR 1.38, 95\% Cl 1.04-1.83), higher WC (OR 1.02, 95\% Cl 1.01-1.04), lower HDL (OR 0.97, 95\% Cl 0.96-0.98), higher HbA1c (OR 1.14, 95\% Cl 1.02-1.26), and the presence of HCV (OR $1.44,95 \% \mathrm{Cl} 1.05-1.98$ ) were significantly associated with a higher risk of CKD. 
Table 3

Association between demographics, characteristics and the risk of chronic kidney disease of the study subjects $(N=2,387)$

\begin{tabular}{|c|c|c|c|c|}
\hline & Univariate analysis & & $\begin{array}{l}\text { Multivariable } \\
\text { analysis }\end{array}$ & \\
\hline Explanatory variable & OR $(95 \% \mathrm{Cl})$ & $P$ & OR $(95 \% \mathrm{Cl})$ & $P$ \\
\hline Female & $0.73(0.58-0.92)$ & 0.008 & & \\
\hline Age, per year & $1.09(1.08-1.10)$ & $<0.001$ & $1.08(1.07-1.10)$ & $<0.001$ \\
\hline Education level, per year & $0.88(0.86-0.90)$ & $<0.001$ & & \\
\hline $\begin{array}{l}\text { Intake vegetable } \geq 3 \text { portions } \\
\text { per day }\end{array}$ & $0.62(0.49-0.79)$ & $<0.001$ & & \\
\hline $\begin{array}{l}\text { Intake fruit } \geq 2 \text { portions per } \\
\text { day }\end{array}$ & $0.56(0.44-0.70)$ & $<0.001$ & $0.79(0.61-1.01)$ & 0.065 \\
\hline $\begin{array}{l}\text { Intake of water } \geq 1500 \mathrm{cc} \text { per } \\
\text { day }\end{array}$ & $0.67(0.53-0.84)$ & 0.001 & & \\
\hline Irregular exercise & $1.38(1.06-1.80)$ & 0.015 & $1.38(1.04-1.83)$ & 0.027 \\
\hline Smoking & $1.24(0.93-1.65)$ & 0.135 & & \\
\hline Betel & $1.41(0.98-2.02)$ & 0.061 & & \\
\hline Alcoholic drinking & $1.13(0.79-1.64)$ & 0.501 & & \\
\hline Waist circumference, $\mathrm{cm}$ & $1.04(1.03-1.05)$ & $<0.001$ & $1.02(1.01-1.04)$ & 0.001 \\
\hline Systolic blood pressure, $\mathrm{mmHg}$ & $\begin{array}{l}1.01(1.002- \\
1.013)\end{array}$ & 0.006 & & \\
\hline $\begin{array}{l}\text { Diastolic blood pressure, } \\
\mathrm{mmHg}^{\star}\end{array}$ & $0.98(0.97-0.99)$ & $<0.001$ & & \\
\hline $\begin{array}{l}\text { High-density lipoprotein, } \\
\text { mg/dL }\end{array}$ & $0.96(0.95-0.97)$ & $<0.001$ & $0.97(0.96-0.98)$ & $<0.001$ \\
\hline $\begin{array}{l}\text { Glycosylated hemoglobin, } \\
\mathrm{mg} / \mathrm{dL}\end{array}$ & $1.31(1.20-1.43)$ & $<0.001$ & $1.14(1.02-1.26)$ & 0.015 \\
\hline Triglyceride, mg/dL & $\begin{array}{l}1.002(1.001- \\
1.003)\end{array}$ & $<0.001$ & & \\
\hline
\end{tabular}

$\mathrm{OR}$, odds ratio; $\mathrm{Cl}$, confidence interval; $\mathrm{BMI}$, body mass index; $\mathrm{ALT}$, alanine aminotransferase; $\mathrm{AST}$, aspartate aminotransferase; eGFR, estimated Glomerular filtration rate; HBV, hepatitis B virus; $\mathrm{HCV}$, hepatitis C virus;

* Diastolic blood pressure was not included in the multivariable model due to its collinearity with systolic blood pressure;

\# AST was not included in the multivariable model due to its collinearity with ALT. 


\begin{tabular}{|c|c|c|c|c|}
\hline & \multicolumn{2}{|l|}{ Univariate analysis } & \multicolumn{2}{|l|}{$\begin{array}{l}\text { Multivariable } \\
\text { analysis }\end{array}$} \\
\hline ALT, U/L & $\begin{array}{l}1.01(0.99997- \\
1.015)\end{array}$ & 0.051 & & \\
\hline AST, U/L\# & $\begin{array}{l}0.99(0.988- \\
1.002)\end{array}$ & 0.146 & & \\
\hline \multicolumn{5}{|c|}{ HBV and HCV status } \\
\hline Non-hepatitis & Reference & Reference & Reference & Reference \\
\hline HBV & $0.63(0.39-1.03)$ & 0.068 & $0.90(0.53-1.51)$ & 0.679 \\
\hline $\mathrm{HCV}$ & $2.03(1.51-2.72)$ & $<0.001$ & $1.44(1.05-1.98)$ & 0.025 \\
\hline \multicolumn{5}{|c|}{$\begin{array}{l}\text { OR, odds ratio; } \mathrm{Cl} \text {, confidence interval; BMI, body mass index; } \mathrm{ALT} \text {, alanine aminotransferase; } \mathrm{AST} \text {, } \\
\text { aspartate aminotransferase; eGFR, estimated Glomerular filtration rate; HBV, hepatitis B virus; HCV, } \\
\text { hepatitis C virus; }\end{array}$} \\
\hline \multicolumn{5}{|c|}{$\begin{array}{l}\text { * Diastolic blood pressure was not included in the multivariable model due to its collinearity with } \\
\text { systolic blood pressure; }\end{array}$} \\
\hline \multicolumn{5}{|c|}{ \# AST was not included in the multivariable model due to its collinearity with ALT. } \\
\hline
\end{tabular}

As shown in Fig. 1, a greater reduction in renal function was associated with a higher number of MetS components in the subjects with HCV (one, three, and five components of MetS associated with a median eGFR of $86.4,77.1$, and $64.5 \mathrm{~mL} / \mathrm{min} / 1.73 \mathrm{~m}^{2}$, respectively). Finally, the effect of regular exercise on the risk of CKD was analyzed in the groups stratified by hepatitis status. The effect of irregular exercise on the risk of CKD was similar among the non-hepatitis, HBV, and HCV groups (Supplementary Table).

\section{Discussion}

In this community-based study conducted in an area where viral hepatitis is hyperendemic, HCV seropositivity was significantly related to CKD complicated with unhealthy dietary behaviors and multiple metabolic disturbances. Overall, $12.8 \%$ of all participants were HCV seropositive, and HCV seropositivity increased the risk of CKD by 44\% compared to the non-hepatitis participants (OR 1.44, 95\% $\mathrm{Cl} 1.05-1.98)$, which is compatible with the results of a previous meta-analysis (HR 1.39, 95\% $\mathrm{Cl} 1.14-1.69$ ) (6). From another perspective, effective HCV treatment could decrease the $30 \%$ risk of incidental CKD (5). Beyond the traditional risk factors for CKD, HCV infection may play a crucial role in progressive renal dysfunction, and early detection of HCV seropositivity during health check-ups represents an emergent issue in rural areas.

This study found patients with HCV and CKD exhibited deterioration in multiple metabolic indices, and MetS significantly increased the risk of CKD by $50 \%$ and was associated with a greater annual decline in eGFR (9, 18-21). A high prevalence of MetS (24.7-35\%) in HCV cohorts was noted in previous studies 
(22-24); however, the rate of MetS among the HCV group was $58.8 \%$ in our study. Individuals with HCV had higher potential risks of CKD because of older age, lower $\mathrm{HDL}$, and higher $\mathrm{HbA1c}$, which also contribute to advanced vascular atherosclerosis and diabetic kidney disease $(9,18,25,26)$. Individuals with HCV with MetS were 3.8 times more likely to fail anti-viral treatment than non-HCV subjects $(27,28)$, and incomplete viral eradication can lead to CKD through extra-hepatic immune injury. Our study found that higher HDL could protect against CKD, while HCV eradication might cancel out the suppressive effect of chronic HCV infection on lipid metabolism (29).

Regular exercise was shown to improve physical performance and fitness, cardiopulmonary function, and quality of life in patients with CKD (28-30). However, the effects of exercise on eGFR in current studies are conflicting. Although a meta-analysis reported exercise led to an increase in eGFR and decreased BMI, but not HDL (7), other studies revealed exercise improved HDL and did not significantly change eGFR (30-32). Our study demonstrates that irregular exercise was an independent risk factor for CKD; however, the frequency of irregular exercise (average 69.5\%) was extremely high, regardless of the presence or absence of either form of viral hepatitis. We also assessed the effect of irregular exercise in the patient groups stratified by viral seropositivity, and found physical activity may provide additional benefits in terms of maintenance of renal function in individuals with HCV and MetS comorbidity. Community health efforts are necessary to enhance education and promote physical activity because the average rate of irregular exercise is relatively high.

Dietary interventions have been proposed as an approach to improve CKD outcomes in the last decade. Healthy diets are considered to contain a low animal/vegetable protein ratio and high proportions of vegetables, legumes, and fruits $(33,34)$. A plant-dominated low-protein diet of $0.6-0.8 \mathrm{~g} \mathrm{protein} / \mathrm{kg} / \mathrm{day}$ composed of more than $50 \%$ plant-based sources has been suggested as a pragmatic and safe goal (34, 35). Healthy dietary behaviors were associated with a lower risk of CKD and slower deterioration of renal function. On the contrary, a high-protein diet was associated with a 1.32-fold increased risk of rapid decline in eGFR $(8,36,37)$. The effect of unhealthy dietary behaviors on individuals with HCV is rarely discussed in the literature. Higher dietary cholesterol intake was related to a higher risk of advanced liver fibrosis, and soy supplements were related to lower liver inflammation $(38,39)$. Thus, maintaining healthy dietary behaviors may provide benefits in both CKD and chronic hepatitis. In our study population, the HCV patients were less likely to have healthy dietary behaviors, which could be one possible factor leading to the higher percentage of CKD in this group than the other groups. However, further research is required to identify the composition of dietary interventions for HCV patients with CKD.

The study has several limitations. This was a cross-sectional study without evidence of long-term observations of renal function (eGFR). We were unable to obtain detailed data on viral activity or virus load. Our study participants lived in rural areas with a high prevalence of HCV and had a high mean age, which may result in a higher prevalence of CKD. The study was based on data from a community health promotion program conducted in a local hospital during the daytime. Thus, patients with fixed working hours or limited ambulatory ability may not have participated in this program, which could have led to 
exclusion of more male individuals and more severely ill patients. Moreover, we could not obtain data on the degree of physical activity and exercise, and variation of effect on CKD is unavoidable.

\section{Conclusions}

HCV seropositivity, metabolic disturbances, and irregular exercise were significantly associated with CKD in this community where viral hepatitis is hyperendemic. Effective viral eradication of HCV and aggressive health promotion of physical activity may help to reduce the occurrence of CKD. The associations between HCV, MetS, and renal dysfunction need to be explored further using long-term studies.

\section{List Of Abbreviations}

HCV, hepatitis C virus; HBV, hepatitis B virus; CKD, chronic kidney disease; eGFR, estimated glomerular filtration rate; $\mathrm{HbA1c}$, glycosylated hemoglobin; TG, triglyceride; $\mathrm{HDL}$, high-density lipoprotein; $W C$, waist circumference; MetS, metabolic syndrome; AST, aspartate aminotransferase; ALT, alanine aminotransferase

\section{Declarations}

Ethics approval and consent to participate: This study was approved by the Institutional Review Board (IRB NO: 201900222A3).

Consent for publication: Not applicable

Availability of data and materials: The datasets used and/or analysed during the current study are available from the corresponding author on reasonable request.

Competing interests: The authors declare that they have no competing interests.

Funding: None

Authors' contributions: All authors contributed to statistical analysis and writing of the study. Mei-Yen Chen and Po-Chang Wang participated in study design, acquisition of the data, critical review and wrote the manuscript; Ming-Shyan Lin participated in acquisition of data and designed the research; ChunLiang Lin, Chang-Min Chung, and Yu-Sheng Lin participated in the analysis and interpretation of data; YiFang Wu collected data and contributed to study direction.

Acknowledgements: The authors thank Alfred Hsing-Fen Lin and Ben Yu-Lin Chou for assistance with statistics.

\section{References}


1. Global prevalence and genotype. distribution of hepatitis $C$ virus infection in 2015: a modelling study. Lancet Gastroenterol Hepatol. 2017 Mar;2(3):161-76.

2. Kurbanova N, Qayyum R. Association of Hepatitis C Virus Infection with Proteinuria and Glomerular Filtration Rate. Clin Transl Sci. 2015 Oct;8(5):421-4.

3. Chen YC, Chiou WY, Hung SK, Su YC, Hwang SJ. Hepatitis $C$ virus itself is a causal risk factor for chronic kidney disease beyond traditional risk factors: a 6-year nationwide cohort study across Taiwan.BMC Nephrol. 2013 Sep 6;14:187.

4. Zhang H, Xu H, Wu R, Yu G, Sun H, Lv J, et al. Association of Hepatitis $\mathrm{C}$ and B Virus Infection with CKD and Impact of Hepatitis C Treatment on CKD. Sci Rep. 2019 Feb;13(1):1910. 9.

5. Park H, Chen C, Wang W, Henry L, Cook RL, Nelson DR. Chronic hepatitis C virus (HCV) increases the risk of chronic kidney disease (CKD) while effective HCV treatment decreases the incidence of CKD. Hepatology. 2018 Feb;67(2):492-504.

6. Li M, Wang P, Yang C, Jiang W, Wei X, Mu X, et al. A systematic review and meta-analysis: Does hepatitis $C$ virus infection predispose to the development of chronic kidney disease? Oncotarget. 2017 Feb 7;8(6):10692-10702.

7. Zhang L, Wang Y, Xiong L, Luo Y, Huang Z, Yi B. Exercise therapy improves eGFR, and reduces blood pressure and BMI in non-dialysis CKD patients: evidence from a meta-analysis. BMC Nephrol. 2019 Oct;29(1):398. 20(.

8. Kim H, Caulfield LE, Garcia-Larsen V, Steffen LM, Grams ME, Coresh J, et al. Plant-Based Diets and Incident CKD and Kidney Function. Clin J Am Soc Nephrol. 2019 May 7;14(5):682-691.

9. Wang Y, Sun B, Sheng LT, Pan XF, Zhou Y, Zhu J, et al. Association between weight status, metabolic syndrome, and chronic kidney disease among middle-aged and elderly Chinese. Nutr Metab Cardiovasc Dis. 2020 Oct 30;30(11):2017-2026.

10. Chen $\mathrm{CH}$, Yang PM, Huang GT, Lee HS, Sung JL, Sheu JC. Estimation of seroprevalence of hepatitis B virus and hepatitis $C$ virus in Taiwan from a large-scale survey of free hepatitis screening participants. J Formos Med Assoc. 2007 Feb;106(2):148-55.

11. Daily dietary guideline. 2018 by Health Promotion Administration of Ministry of Health and Welfare; Accessed June 16,2021. https://www.hpa.gov.tw/Pages/EBook.aspx?nodeid=1208.

12. 2. Classification and Diagnosis of Diabetes. Diabetes Care. 2017 Jan;40(Suppl 1):11-24. doi:10.2337/dc17-S005.

13. Cavero-Redondo I, Martínez-Vizcaíno V, Álvarez-Bueno C, Agudo-Conde C, Lugones-Sánchez C, García-Ortiz L. Metabolic Syndrome Including Glycated Hemoglobin A1c in Adults: Is It Time to Change?J Clin Med. 2019 Dec 1;8(12):2090.

14. .Park SH, Yoon JS, Won KC, Lee HW. Usefulness of glycated hemoglobin as diagnostic criteria for metabolic syndrome. J Korean Med Sci. 2012 Sep;27(9):1057-61.

15. Alberti KG, Zimmet P, Shaw J. Metabolic syndrome-a new world-wide definition. A Consensus Statement from the International Diabetes Federation. Diabet Med. 2006 May;23(5):469-80. 
16. Metabolic syndrome study manual. 2016 by Health Promotion Administration of Ministry of Health and Welfare; Accessed June 16,2021. https://www.hpa.gov.tw/Pages/EBook.aspx?nodeid=1181.

17. Heinze G, Wallisch C, Dunkler D. Variable selection - A review and recommendations for the practicing statistician. Biom J. 2018 May;60(3):431-49.

18. Kawamoto R, Akase T, Ninomiya D, Kumagi T, Kikuchi A. Metabolic syndrome is a predictor of decreased renal function among community-dwelling middle-aged and elderly Japanese. Int Urol Nephrol. 2019 Dec;51(12):2285-94.

19. DeBoer MD, Filipp SL, Musani SK, Sims M, Okusa MD, Gurka M. Metabolic Syndrome Severity and Risk of CKD and Worsened GFR: The Jackson Heart Study. Kidney Blood Press Res. 2018;43(2):55567.

20. Alizadeh S, Ahmadi M, Ghorbani Nejad B, Djazayeri A, Shab-Bidar S. Metabolic syndrome and its components are associated with increased chronic kidney disease risk: Evidence from a metaanalysis on 11109003 participants from 66 studies. Int J Clin Pract. 2018 May 23;e13201.

21. Maleki A, Montazeri M, Rashidi N, Montazeri M, Yousefi-Abdolmaleki E. Metabolic syndrome and its components associated with chronic kidney disease. J Res Med Sci. 2015 May;20(5):465-9.

22. Li WC, Lee YY, Chen IC, Sun C, Chiu FH, Chuang CH. Association between the hepatitis B and C viruses and metabolic diseases in patients stratified by age.Liver Int. 2013 Sep;33(8):1194-202.

23. Kuo YH, Kee KM, Wang JH, Hsu NT, Hsiao CC, Chen Y, et al. Association between chronic viral hepatitis and metabolic syndrome in southern Taiwan: a large population-based study. Aliment Pharmacol Ther. 2018 Nov;48(9):993-1002.

24. Banks DE, Bogler Y, Bhuket T, Liu B, Wong RJ. Significant disparities in risks of diabetes mellitus and metabolic syndrome among chronic hepatitis C virus patients in the U.S. Diabetes Metab Syndr. 2017 Nov;11Suppl 1:S153-S158.

25. Chen J, Kong X, Jia X, Li W, Wang Z, Cui M, et al. Association between metabolic syndrome and chronic kidney disease in a Chinese urban population. Clin Chim Acta. 2017 Jul;470:103-8.

26. Yun HR, Kim H, Park JT, Chang TI, Yoo TH, Kang SW, et al. Obesity, Metabolic Abnormality, and Progression of CKD. Am J Kidney Dis. 2018 Sep;72(3):400-10.

27. Hanouneh IA, Feldstein AE, Lopez R, Yerian L, Pillai A, Zein CO, et al. Clinical significance of metabolic syndrome in the setting of chronic hepatitis C virus infection. Clin Gastroenterol Hepatol. 2008 May;6(5):584-9.

28. Chaudhari R, Fouda S, Sainu A, Pappachan JM. Metabolic complications of hepatitis C virus infection. World J Gastroenterol. 2021 Apr;7(13):1267-82. 27(.

29. Shimizu K, Soroida Y, Sato M, Hikita H, Kobayashi T, Endo M, et al. Eradication of hepatitis $C$ virus is associated with the attenuation of steatosis as evaluated using a controlled attenuation parameter. Sci Rep. 2018 May;18(1):7845. 8(.

30. Pei G, Tang Y, Tan L, Tan J, Ge L, Qin W. Aerobic exercise in adults with chronic kidney disease (CKD): a meta-analysis. Int Urol Nephrol. 2019 Oct;51(10):1787-95. 
31. Hellberg M, Höglund P, Svensson P, Clyne N. Randomized Controlled Trial of Exercise in CKD-The RENEXC Study. Kidney Int Rep. 2019 Apr 9;4(7):963-976.

32. Hiraki K, Shibagaki Y, Izawa KP, Hotta C, Wakamiya A, Sakurada T, et al. Effects of home-based exercise on pre-dialysis chronic kidney disease patients: a randomized pilot and feasibility trial. BMC Nephrol. 2017 Jun;17(1):198. 18(.

33. van Westing AC, Küpers LK, Geleijnse JM. Diet and Kidney Function: a Literature Review. Curr Hypertens Rep. 2020 Feb;3(2):14. 22 (.

34. Kalantar-Zadeh K, Joshi S, Schlueter R, Cooke J, Brown-Tortorici A, Donnelly M, et al. Plant-Dominant Low-Protein Diet for Conservative Management of Chronic Kidney Disease. Nutrients. 2020 Jun 29;12(7):1931.

35. Rhee CM, Ahmadi SF, Kovesdy CP, Kalantar-Zadeh K. Low-protein diet for conservative management of chronic kidney disease: a systematic review and meta-analysis of controlled trials. J Cachexia Sarcopenia Muscle. 2018 Apr;9(2):235-45.

36. Jhee JH, Kee YK, Park S, Kim H, Park JT, Han SH, et al. High-protein diet with renal hyperfiltration is associated with rapid decline rate of renal function: a community-based prospective cohort study. Nephrol Dial Transplant. 2020 Jan;35(1)(1):98-106.

37. Liu HW, Tsai WH, Liu JS, Kuo KL. Association of Vegetarian Diet with Chronic Kidney Disease. Nutrients. 2019 Jan 27;11(2):279.

38. Yu L, Morishima C, loannou GN. Dietary cholesterol intake is associated with progression of liver disease in patients with chronic hepatitis $C$ : analysis of the Hepatitis $C$ Antiviral Long-term Treatment Against Cirrhosis trial. Clin Gastroenterol Hepatol. 2013 Dec;11(12):1661-6.e1-3.

39. Oliveira LP, de Jesus RP, Boulhosa RS, Mendes CM, Gnoatto MC, Lemaire DC, et al. Effect of soy protein supplementation in patients with chronic hepatitis $\mathrm{C}$ : a randomized clinical trial. World $\mathrm{J}$ Gastroenterol. 2012 May 14;18(18):2203-11.

\section{Figures}




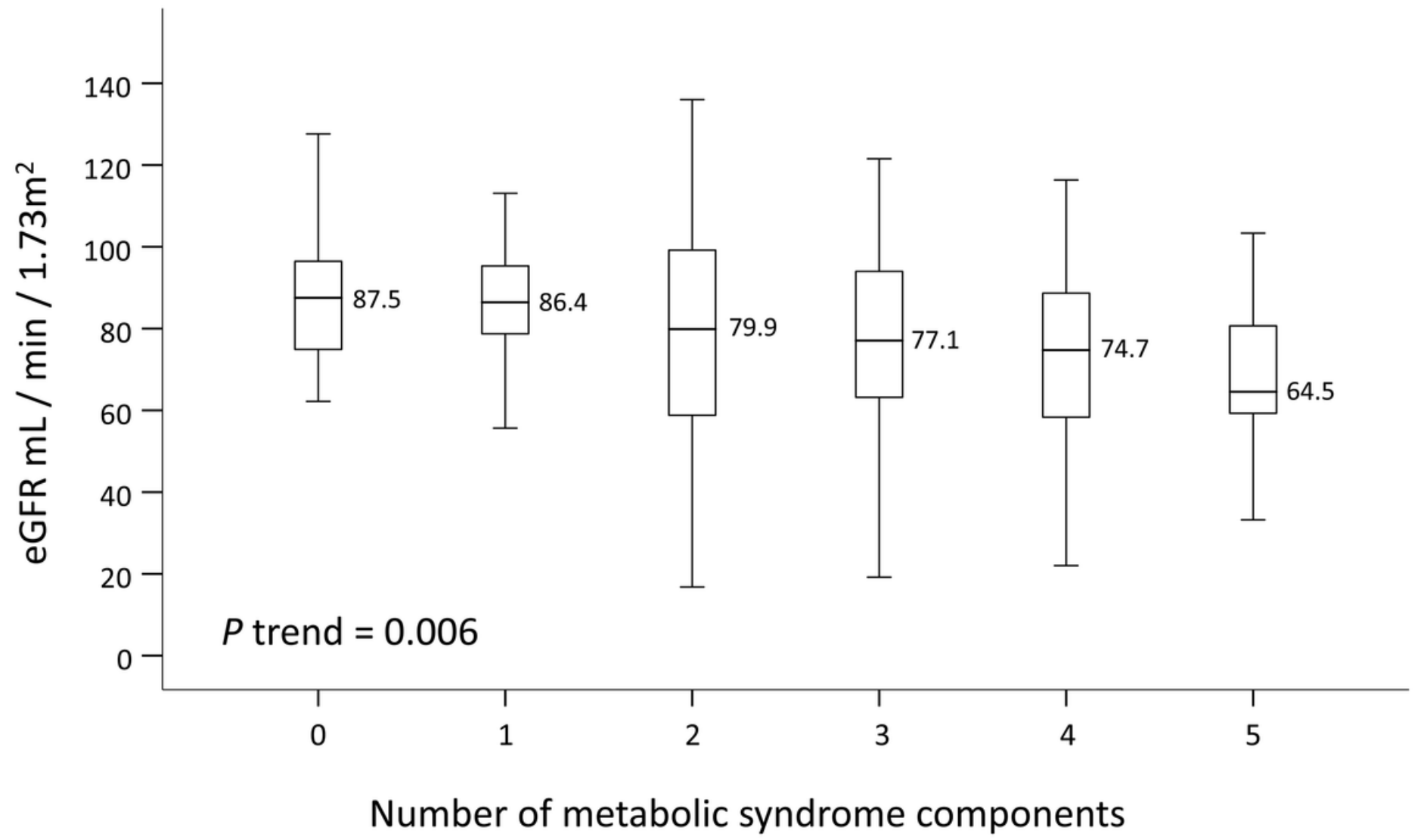

Figure 1

The renal function according to different numbers of metabolic syndrome components in the subjects with hepatitis $C$ virus infection. The $P$ value for trend was obtained from the linear contrast in the general linear model. eGFR, estimated Glomerular filtration rate.

\section{Supplementary Files}

This is a list of supplementary files associated with this preprint. Click to download.

- SupplementaryTable.docx

- STROBEchecklistcrosssectional1.docx 